\title{
AUTOREFLEKSJE
}

\section{Franciszek Gronowski}

Motto

90 mieć lat to nie grzech - to raczej natury pech

(własne)

Od razu na wstępie, nachodzi mnie taka oto refleksja, że pisać sam o sobie to można albo DOBRZE, albo wcale (jak na pogrzebie zmarłego). Jednak coś musze napisać. Będzie to głównie uzupełnienie merytoryczne i czasowe do broszury wydanej w 2002 roku przez Uniwersytet Szczeciński na moje 75-lecie urodzin. Nie każdy ją ma, a i „stuknęło” dalszych 15 lat, więc coś niecoś trzeba przypomnieć i dodać; nie tyle chronologicznie - czasowo, co problemowo.

W styczniu 1947 roku „wylądowałem” w Szczecinie, jako student drugiego rocznika, powołanej w 1946 roku Akademii Handlowej w Poznaniu, Oddział w Szczecinie - pierwszej wyższej polskiej uczelni na Pomorzu Zachodnim.

I tak się zaczęło, i tak trwało przez lata - nauka, praca. Najpierw jako asystent wolontariusz (1948); pierwszy etat młodszego asystenta (1949); dalej w różnym układzie: AH - WSE Szczecin, SGPiS - Warszawa, Politechnika Szczecińska, Uniwersytet, WSM (Akademia Morska), Wyższa Szkoła Ekonomiczno-Turystyczna... Wyższa Szkoła Gospodarki w Bydgoszczy (2010-2016). Doktorat i habilitacja WSE Sopot - Uniwersytet Gdański. Profesor zwyczajny (tytularny) 1983 rok. Pełniłem różne funkcje kierowniczo-zarządcze; od kierownika zakładu, katedry, dziekana po rektora.

Ze Szczecinem i jego uczelniami związany byłem do 2008 roku. W końcu tegoż roku „wyemigrowałem” do Bydgoszczy (względy rodzinne). Tutaj „zapolowała” na mnie Wyższa Szkoła Gospodarki, gdzie tworzono kierunek Ekonomia, a w nim specjalność Transport - Spedycja Logistyka. I tak trwały nadal moje związki ze szkolnictwem wyższym. Końcowe lata nie tyle z nauką, co z dydaktyką. Ostatni wykład ze studentami odbyłem 24 czerwaca 2016 roku. Nieprzerwana praca etatowa to 67 lat (tak, tak - lata 1949-2016).

Ale wystarczy tych „wyliczanek”, wróćmy do bardziej istotnych spraw merytorycznych. Uczyć się, studiować, być jak najbliżej praktyki życia gospodarczego - to z jednej strony, a z drugiej - pokazywać studentom wiedzę poprzez dydaktykę. Oto jedna z moich głównych 
idei życiowych. Tym celom się „poświęciłem”. Wychodząc z tych przesłanek, w swoim działaniu zawodowym, głównie ukierunkowałem się na człowieka, a nie na „pióro”. Świadomie preferowałem kształtowanie nowych kadr morskich, a nie mnożenie publikacji. Efekt - to wypromowanie około 1000 magistrów i 24 doktorów nauk ekonomicznych, specjalności morskiej.

Ten ścisły związek „nauki z praktyką” realizowałem sam osobiście, realizowali go także moi późniejsi liczni absolwenci, zajmując kierownicze stanowiska w podmiotach gospodarczych i instytucjach. Wśród przykładów mojej aktywności na tym polu można wymienić: kierowanie przez ponad 20 lat Radą Techniczno-Ekonomiczną PŻM; stałe członkostwo w Komisji Morskiej PIHZ czy współorganizowanie 25 tzw. Sejmików Morskich corocznie od 1985 roku do 2009 roku. Ta ostatnia inicjatywa (organizowana wraz z PAX - Civitas Christiana) w miastach polskiego wybrzeża Bałtyku - od Świnoujścia do Elbląga - inspirowała samorządy terytorialne i władze lokalne do głębszego zainteresowania się sprawami morskimi i korzyściami stąd płynącymi. Była to również ważna forma popularyzowania w społeczeństwie świadomości morskiej. Co do czasu i ważności, była to jedyna w powojennej Polsce tego rodzaju inicjatywa. A co dzisiaj...?

Ze studentów - absolwentów, będących dyrektorami - prezesami, przykładowo wymienię: P. Szynkaruk - PŻM, A. Wysocki - Euroafrica, M. Bardasz - Żegluga Szczecińska, B. Trzciński - Bulk Cargo - Port Szczecin czy J. Wójtowicz - C. Hartwig Szczecin. W różnych okresach podobnych przykładów było znacznie więcej; wielu z nich to już dzisiaj też emeryci, jak piszący te słowa. Tak, bo dotyczy to prawie trzech pokoleń studentów - absolwentów.

Z moich doktorantów wielu kierowało różnymi przedsiębiorstwami i instytucjami gospodarki morskiej (także za granicą), część związana z nauką to profesorowie (już także emeryci). Proszę - co za „karuzela życia”.

Żeby jednak nie „przesłodzić” tego dania, przejdźmy na chwilę do innej cechy osobowej autora. Obok poważnego traktowania profesji naukowca i dydaktyka, ciągle tkwił we mnie felietonista - satyryk. Uznawany nawet byłem za wydziałowego „rozśmieszacza”, prezentując swoje felietony na spotkaniach integracyjnych pracowników przed nowym rokiem akademickim (najczęściej nad morzem). To zostało mi aż do dzisiaj, czego wyrazem jest obecny styl moich wypowiedzi.

Doczekałem się licznych nagród, dyplomów, odznaczeń - od państwowych (Złoty Krzyż Zasługi aż do Krzyża Komandorskiego), regionalnych, resortowych, uczelnianych i innych. Mam tego pół szuflady. Niektóre z nich były kiedyś „chlebowymi”; dzisiaj już tylko „leżakowymi”. Osobiście najbardziej cenię sobie złotą oznakę „Zasłużony dla rozwoju Gospodarki Morskiej”.

Kończąc swoją „spowiedź” i oczekując na „rozgrzeszenie” śmiem twierdzić, że wykorzystałem w życiu prawie wszystkie możliwości jakie dał mi los. Możliwości, zarówno dla rozwoju własnego, jak również - i to szczególnie - dla przekazywania wiedzy zawodowo-życiowej trzem następnym pokoleniom studentów. Mogę więc uczciwie powiedzieć, że nie zmarnowałem swojego życia, nie rozmieniłem go na drobne.

Daję więc sobie rozgrzeszenie i ze spokojem patrzę w przyszłość.

Z pewnością moi Przyjaciele i Koledzy zweryfikują to co napisałem sam o sobie i dodadzą coś jeszcze - co...? 
Z góry dziękuję IM za życzliwość, ale i za odwagę, by po tylu latach powspominać jak mnie widzieli i zapamiętali.

Moje credo - jako ekonomisty i życiowe - zapisałem już w broszurze z okazji 75-lecia (s. 23 i 139) - więc nie będę go powtarzał.

Spełniony Emeryt

w drodze ku wieczności

Bydgoszcz, koniec 2016 roku 